\title{
PENGARUH JENIS PRODUK TERHADAP VOLUME PENJUALAN HAND PHONE ANDROID DI COUNTER CLINIK ANDROID MADIUN
}

\author{
Khoirul Ikhwan \\ Mahasiswa Prodi Pendidikan Ekonomi IKIP PGRI Madiun
}

\begin{abstract}
Abstrak: Penelitian ini bertujuan (1) Untuk mengetahui bagaimana jenis produk android di Counter Clinik Android Madiun. (2) Untuk mengetahui bagaimana volume penjualan android di Counter Clinik Android Madiun. (3) Untuk mengetahui adakah pengaruh jenis produk terhadap volume penjualan android di Counter Clinik Android Madiun. Hasil penelitian menunjukkan bahwa jenis produk tidak berpengaruh terhadap volume penjualan pada Counter Clinik Android Madiun. Hal ini diperoleh dari perhitungan didapatkan fungsi $\mathrm{Y}=59,83131-0,005596808 \mathrm{x}$. Dalam uji korelasi diperoleh nilai $\mathrm{r}_{\text {hit }}$ sebesar $-0,573681$ sedangkan $r_{\text {tabel }}$ sebesar 0,514 . Hal ini berarti $r_{\text {hit }}<r_{\text {tabel }}(-0,573681<0,514)$. Jadi dapat diartikan tidak ada hubungan antara jenis produk terhadap volume penjualan hand phone jenis android di Counter Clinik Android Madiun. Sedangkan dalam uji t diperoleh $\mathrm{t}_{\text {hitung }}-2,69$ sedangkan $\mathrm{t}_{\text {tabel }}$ sebesar 1,753 . Hal ini berarti $\mathrm{t}_{\text {hit }} \leq \mathrm{t}_{\text {tabel }}(-2,69 \leq 1,753)$. Yang artinya tidak ada pengaruh antara jenis produk terhadap volume penjualan hand phone Android di Counter Clinik Android Madiun.
\end{abstract}

Kata Kunci : Jenis Produk dan Volume Penjualan

\section{PENDAHULUAN}

Perkembangan teknologi pada saat ini mengalami kemajuan yang sangat pesat. Khususnya perkembangan pada teknologi komunikasi yaitu hand phone. Hand phone telah menjadi salah satu kebutuhan bagi semua kalangan masyarakat yang sangat penting. Pandangan masyarakat tentang hand phone juga sudah semakin berkembang seiring dengan kemajuan teknologi dan tingkat pendapatan masyarakat, di mana hand phone dibutuhkan bukan hanya untuk memenuhi kebutuhan komunikasi saja, tetapi juga sebagai gaya hidup masyarakat. Situasi seperti inilah yang dimanfaatkan oleh perusahaan hand phone untuk masuk ke dalam pasar. Setiap perusahaan dituntut untuk menghasilkan produk yang sesuai dengan keinginan dan selera konsumen. Hal ini sangat penting bagi kelangsungan hidup perusahaan dan produk yang dihasilkan. Perlu disadari bahwa dalam kondisi pasar yang kompetitif, banyak sekali produk yang dilepas ke pasar sehingga konsumen dihadapkan pada berbagai pilihan yang semakin beragam, hal ini akan memberikan keleluasaan dalam menentukan produk mana yang diinginkan oleh konsumen, dimana produk tersebut mempunyai kualitas yang baik dengan harga yang terjangkau oleh masyarakat.

Di Indonesia, produsen hand phone memasarkan produknya melalui distributor cabang masing-masing di setiap daerah. Seperti SAMSUNG, SONY dan LG. Dalam hal ini setiap produk diberi garansi resmi dari pabrik dan garansi distributor. Hal ini bertujuan agar konsumen merasa aman di dalam pembelian dan penggunaan produk yang ada. Serta penyediaan servis center serta outlet dalam setiap penjualan resmi. Dalam memperluas pasar yang ada, setiap kantor 
pemasaran memilih untuk membuka cabang atau outlet agar produk yang ada dapat dengan mudah didapatkan oleh konsumen. Secara umum, setiap counter hand phone dalam kegiatannya selalu memiliki tujuan yaitu penjualan serta penyediaan produk yang sesuai dengan selera konsumen dengan harga yang bersaing agar target penjualan dapat tercapai secara sempurna. Begitu pula dengan Counter Clinik Android Madiun.

Counter Clinik Android Madiun adalah salah satu counter yang menyediakan serta menjual hand phone baik secara eceran maupun partai besar. Counter Clinik Android Madiun, merupakan salah satu outlet yang menjual berbagai produk android dari berbagai merk hand phone android. Hal ini dilakukan karena banyaknya jenis hand phone dan merk yang beredar sehingga sebagai strategi bisnis Counter Clinik Android Madiun dalam penjualan produknya. Basu Swastha (2002:183) berpendapat "Penjualan ini merupakan fungsi yang paling penting dalam pemasaran karena menjadi tulang punggung kegiatan untuk mencapai pasar yang dituju". Freddy Rangkuti (2009:57) berpendapat "Volume penjualan adalah pencapaian penjualan yang dinyatakan secara kuantitatif dari segi fisik atau volume atau unit suatu produk". Dalam rangka meningkatkan volume penjualannya, Counter Clinik Android Madiun menyediakan banyak pilihan berbagai macam produk hand phone yang dijual, mulai dari jenis entri level hingga hig hend. Dengan jumlah 17 jenis hand phone android yang tersedia, pelanggan akan dimanjakan dengan berbagai pilihan produk hand phone dengan tipe dan teknologi hand phone yang sesuai dengan selera konsumen. Dimana kepuasan konsumen merupakan hal yang sangat diutamakan oleh Counter Clinik Android Madiun.

Philip Kotler (2008:4) berpendapat "Produk (product) adalah segala sesuatu yang dapat ditawarkan kepada pasar untuk memuaskan suatu keinginan atau kebutuhan. Termasuk barang fisik, jasa, pengalaman, acara, orang, tempat, property, organisasi, informasi dan ide".

Gunawan Adisaputro (2008:182) berpendapat "jumlah barang yang direncanakan untuk dijual (tercantum dalam anggaran penjualan) yang dihubungkan dengan kebijaksanaan tingkat produksi dan tingkat persediaan, akan menghasilkan jumlah barang yang harus diproduksi oleh perusahaan menurut waktu dan menurut jenis barangnya. Dalam pelaksanaannya pada kehidupan perusahaan sehari-hari terdapat kebijaksanaan tertentu tentang tingkat produksi dan tingkat persediaan barang".

Sehingga pada umumnya, konsumen memiliki banyak pilihan dalam membeli produk hand phone yang diinginkan, mulai dari pemilihan counter hand phone hingga jenis produk hand phone yang ingin dibeli. Dengan jumlah produk hand phone yang bervariasi maka akan mempermudah konsumen dalam menentukan pilihan mereka.

Setiap jenis produk memiliki peran yang berbeda dan sangat penting dalam proses penjualan, dengan adanya berbagai produk maka konsumen akan memiliki pilihan di dalam memilih jenis yang diinginkan sesuai dengan selera masing-masing sesuai dengan kebutuhan.

Hani Handoko (2002:54) "Kualitas merupakan faktor yang terdapat dalam suatu produk yang menyebabkan produk tersebut bernilai sesuai dengan maksud untuk apa produk itu dibuat".

"Apabila perusahaan ingin mempertahankan keunggulan kompetitifnya dalam pasar, perusahaan harus mengerti aspek dimensi apa saja yang digunakan oleh konsumen untuk membedakan produk yang dijual perusahaan tersebut dengan produk 
pesaing” (http://jurnal-sdm.blogspot.com/ 2009/07/produk-definisi-klasifikasidimensi_30.html).

Dimensi kualitas produk tersebut terdiri dari :

1) Performance (kinerja), berhubungan dengan karakteristik operasi dasar dari sebuah produk.

2) Durability (daya tahan), yang berarti berapa lama atau umur produk yang bersangkutan bertahan sebelum produk tersebut harus diganti. Semakin besar frekuensi pemakaian konsumen terhadap produk maka semakin besar pula daya tahan produk.

3) Conformance to specifications (kesesuaian dengan spesifikasi), yaitu sejauh mana karakteristik operasi dasar dari sebuah produk memenuhi spesifikasi tertentu dari konsumen atau tidak ditemukannya cacat pada produk.

4) Features (fitur), adalah karakteristik produk yang dirancang untuk menyempurnakan fungsi produk atau menambah ketertarikan konsumen terhadap produk.

5) Reliability (reliabilitas), adalah probabilitas bahwa produk akan bekerja dengan memuaskan atau tidak dalam periode waktu tertentu. Semakin kecil kemungkinan terjadinya kerusakan maka produk tersebut dapat diandalkan.

6) Aesthetics (estetika), berhubungan dengan bagaimana penampilan produk bisa dilihat dari tampak, rasa, bau dan bentuk dari produk.

7) Perceived Quality (kesan kualitas), sering dibilang merupakan hasil dari penggunaan pengukuran yang dilakukan secara tidak langsung karena terdapat kemungkinan bahwa konsumen tidak mengerti atau kekurangan informasi atas produk yang bersangkutan. Jadi, persepsi konsumen terhadap produk didapat dari harga, merek, periklanan, reputasi dan negara asal.

"Semakin tinggi pula kualitas, semakin tinggi tingkat kepuasan pelanggan yang dihasilkan, yang mendukung harga lebih tinggi dan (seringkali) biaya yang lebih rendah" (Philip Kotler 2008:144). Dari pernyataan di atas dapat disimpulkan bahwa kualitas produk sangat berperan dalam keberhasilan suatu produk di pasaran. Jika produk memiliki kualitas baik akan sangat mudah diterima oleh konsumen, begitu juga sebaliknya, jika produk memiliki kualitas rendah akan sulit diterima oleh konsumen. Hal ini disebabkan sifat konsumen yang selektif dalam pemilihan produk dan biasanya konsumen beranggapan bahwa jenis produk yang harganya mahal memiliki kualitas yang tinggi, begitu pula sebaliknya.

Kehidupan perusahaan sangat tergantung pada penjualan yang dilakukan. Sehingga perusahaan berlomba-lomba dalam mengembangkan produk dan varian yang ada guna memenuhi pasar dan kepuasan konsumen yang bertujuan untuk meningkatkan volume penjualan yang ada.

Thamrin Abdullah (2012:164) berpendapat "Lini Produk adalah kelompok produk yang berhubungan erat karena fungsinya serupa, dijual kepada kelompok pelanggan yang sama, dipasarkan lewat jenis toko yang sama atau masuk dalam kisaran harga yang sudah ada". Dalam mengembangkan strategi lini produk Pemasar menghadapi sejumlah keputusan, yaitu:

1) Panjang Lini Produk

Panjang lini produk dipengaruhi oleh sasaran perusahaan. Dimana lini itu terlalu pendek bila manajer dapat menambah laba dengan menambah jenis produk atau lini itu terlalu panjang jika manajer dapat meningkatkan laba dengan mengurangi jenis produk. 
Perusahaan yang ingin mengejar pangsa pasar biasanya mempunyai lini produk yang lebih panjang. Manajer lini produk dapat merasakan tekanan untuk menambah produk baru demi pemanfaatan kapasitas mesin berlebihan. Akan tetapi, kalau manajer menambah jenis produk baru, maka hal ini akan menambahkan biaya produksi.

2) Memperpanjang ke Bawah

Ada banyak perusahaan yang semula terletak di ujung atas dari pasar, kemudian memperpanjang lininya ke bawah. Sebuah perusahaan dapat memperpanjang lininya ke bawah karena beberapa alasan, yaitu:

a) Dimana perusahaan pertama kali masuk ke pasar melalui kelas atas untuk membangun citra mutu atau memang bermaksud untuk turun ke kelas bawah.

b) Perusahaan mau menanggapi serangan pesaing di kelas atas dengan menyerbu kelas bawah.

c) Perusahaan dapat menambah produk kelas bawah untuk menutup lubang pasar yang kalau dibiarkan akan menarik pesaing baru.

3) Memperpanjang ke Atas

Perusahaan di pasar kelas bawah mungkin ingin memasuki pasar kelas atas. Mereka mungkin tertarik kecepatan pertumbuhan yang lebih tinggi di kelas atas, atau mereka mungkin hanya ingin memposisikan diri mereka sendiri sebagai manufaktur semua lini. Keputusan memperpanjang lini ke atas mengandung resiko. Pesaing kelas atas tidak hanya membentengi diri dengan baik, tetapi mereka juga dapat menyerang balik dengan memasuki pasar kelas bawah.

4) Memperpanjang ke DuaArah

Perusahaan di pasar kelas menengah mungkin memutuskan untuk memper- panjang lini ke dua arah. Hal ini dapat diartikan dimana pemasar akan melayani setiap segmen yang ada.

5) Mengisi Lini Produk

Gunawan Adisaputro (2010:176) berpendapat "Pengisian lini yaitu menambahkan item baru di antara 2 items yang sudah ada". Produk yang berhubungan erat karena fungsinya serupa, dijual kepada kelompok pelanggan yang berguna untuk menambah pemasukan perusahaan.

6) Moderenisasi Lini Produk

Dalam beberapa kasus, panjang lini produk memadai tetapi lini perlu dipermodern. Dimana isu sentral dalam modernisasi lini produk adalah apakah harus membongkar lini sedikit demi sedikit atau seluruhnya. Dimana dengan adanya pembaruan maka bisa digunakan untuk mengetahui apakah pelanggan dan agen menyukai gaya baru sebelum mengubah keseluruhan lini.

\section{7) Menonjolkan Lini Produk}

Manajer lini produk biasanya memilih satu atau beberapa jenis dalam lini produk yang ditonjolkan. Seringkali manajer menonjolkan model yang dipromosikan di sisi bawah dari lini produk yang berfungsi untuk menggiring konsumen.

Pengembangan lini produk sangat diperlukan oleh suatu perusahaan. Hal ini diperlukan dengan penambahan lini produk yang ada, sehingga akan meningkatkan volume penjualan dari setiap produk yang diproduksi.

Basu Swastha (2002:183) berpendapat "Penjualan ini merupakan fungsi yang paling penting dalam pemasaran karena menjadi tulang punggung kegiatan untuk mencapai pasar yang dituju".

Sedangkan menurut Fredy Rangkuti (2009:57) berpendapat "Penjualan merupa- 
kan pengalihan hak milik atas barang dengan imbalan uang sebagai gantinya dengan persetujuan untuk menyerahkan barang kepada pihak lain dengan menerima pembayaran".

Volume penjualan merupakan faktor yang penting sebagai hasil dari sebuah produksi. Dalam kenaikan penjualan maka akan secara langsung mempengaruhi volume penjualan. Untuk meningkatkan volume penjualan diperlukan cara yang intensif dalam penjualan. Basu Swastha (2008:141) berpendapat "Analisis volume penjualan merupakan suatu studi mendalam tentang masalah "penjualan bersih" dari laporan rugi-laba perusahaan (laporan operasi)".

Hal ini dipertegas oleh pendapat Freddy Rangkuti (2009:57) yang menyatakan "Volume penjualan adalah pencapaian penjualan yang dinyatakan secara kuantitatif dari segi fisik atau volume atau unit suatu produk".

Sehingga dapat diartikan bahwa semakin besar volume penjualan, maka semakin besar laba yang diperoleh perusahaan. Dimana fokus utama yaitu peningkatan volume penjualan untuk menjaga kelangsungan hidup suatu perusahaan.

Volume penjualan merupakan hasil akhir yang selalu diinginkan oleh setiap perusahaan. Dimana terdapatnya selisih antara pendapatan dan biaya yang dikeluarkan oleh suatu perusahaan. Sedangkan faktorfaktor yang mempengaruhi volume penjualan merupakan suatu langkah agar produsen mengetahui kondisi pasar dan apa yang diinginkan oleh konsumen guna menentukan tujuan produksi perusahaan.

Adapun faktor-faktor yang mempengaruhi volume penjualan, yaitu:

1) Kondisi dan Kemampuan Penjual

Basu Swastha (2008:406) berpendapat bahwa "Penjual harus dapat meyakinkan kepada pembelinya agar dapat berhasil mencapai sasaran penjualan yang diharapkan".

2) Kondisi Pasar

Basu Swastha (2002:50) berpendapat "Pasar adalah tempat di mana pembeli dan penjual bertemu dan berfungsi, barang atau jasa tersedia untuk dijual dan terjadi perpindahan hak milik".

3) Modal

Untuk menciptakan suatu usaha, diperlukan modal yang besar. Peran suatu modal sangatlah penting, dengan modal yang besar maka perusahaan akan dapat mengembangkan dan menciptakan produk-produk yang baru. Dimana modal merupakan sarana utama yang diperlukan oleh perusahaan agar dapat terus melanjutkan kegiatannya, serta mengembangkan divisi-divisi perencanaan produk.

4) Kondisi Organisasi Perusahaan

Basu Swastha (2008:407) berpendapat "Pada perusahaan besar, biasanya masalah penjualan ditangani oleh bagian tersendiri (bagian penjualan) yang dipegang oleh orang-orang tertentu/ahli di bidang penjualan".

5) Faktor Lain

Basu Swastha (2008:407) berpendapat "Faktor-faktor lain, seperti: periklanan, peragaan, kampanye dan pemberian hadiah sering mempengaruhi penjualan".

Dalam melakukan penjualan, sebuah perusahaan diharapkan untuk mengetahui kondisi pasar dan selera konsumen. Hal ini bertujuan agar produk yang akan diproduksi dapat diterima oleh konsumen dengan mudah. Dengan adanya faktor-faktor penjulan diharapkan produsen dapat menciptakan produk yang sesuai dengan kondisi pasar. Hal ini bertujuan untuk meningkatkan volume penjualan produk yang ada. 
Keberhasilan sebuah organisasi dalam merealisasikan tujuannya ditentukan oleh kemampuan organisasi bersangkutan dalam mengidentifikasi kebutuhan dan keinginan pasar sasarannya.

Mursid (2010:70) "Konsumen hanya dapat dipengaruhi tetapi tidak dapat dikendalikan dan profitabilitas merupakan hasil akhir yaitu dihasilkan dari seluruh kegiatan di dalam marketing".

Peran marketing mix sangat diperlukan dalam peningkatan volume penjualan. Hal ini dikarenakan sebuah produk tidak akan berhasil dalam pemasaran tanpa adanya faktorfaktor pendukung. Semisal sebuah produk memerlukan iklan di media massa agar keberadaannya dikenal oleh publik secara luas.

Pengaruh jenis produk terhadap volume penjualan dimana jenis produk yang dipasarkan merupakan elemen terpenting dalam proses pemasaran yang tentunya memiliki keterkaitan secara langsung dengan volume penjualan. Kesesuaian penerapan kebijakan yang terkait dengan jenis produk akan menentukan tinggi rendahnya volume penjualan suatu produk.

“... para produsen dan penjual mencoba mempengaruhi pasaran hasil produksinya melalui variabel bukan harga, seperti mutu dan kelengkapan produk mereka, syarat pembayaran, jasa pelayanan yang lain, distribusi yang merata sehingga mempermudah calon pembeli mencari produk mereka, program promosi yang intensif dan sebagainya" (Gunawan Adisaputra, 2010:126).

Dengan banyaknya variasi jenis produk yang ada, akan meningkatkan volume penjualan. Dalam hal ini konsumen akan diberikan keleluasan dalam pemilihan produk yang sesuai dengan setiap selera konsumen.

Berdasarkan uraian di atas, jenis produk memiliki peran yang sangat penting dalam proses penjualan suatu produk yang akan berkaitan dengan tinggi rendahnya volume penjualan. Volume penjualan produk hand phone android di Counter Clinik Cell Madiun, bukan hanya ditentukan dari satu aspek saja melainkan banyak aspek yang akan mendukung peningkatan volume penjualan. Oleh karena itu Counter Clinik Cell Madiun harus selalu berperan aktif guna mencapai target yang telah ada.

Gunawan Adisaputro (2008:182) berpendapat "jumlah barang yang direncanakan untuk dijual (tercantum dalam anggaran penjualan) yang dihubungkan dengan kebijaksanaan tingkat produksi dan tingkat persediaan, akan menghasilkan jumlah barang yang harus diproduksi oleh perusahaan menurut waktu dan menurut jenis barangnya".

Setiap produk memiliki karakteristik yang berbeda-beda sehingga sifat konsumen yang selektif dalam pemilihan produk dan biasanya konsumen beranggapan bahwa jenis produk yang harganya mahal memiliki kualitas yang tinggi, begitu pula sebaliknya.

Telah disebutkan di muka dalam melakukan kegiatan produksi, suatu perusahaan pastinya selalu menciptakan inovasiinovasi baru guna memuaskan keinginan konsumen dan pemilihan type produk yang akan dijual ke dalam pasar. Agar jenis produk tersebut nantinya dapat berdampak positif bagi perusahaan, maka perusahaan perlu berpikir secara bijak terkait dengan jenis produk dan harga produk yang akan dipasarkan kepada para konsumen. Apabila harga produk mahal walau dengan kualitas produk yang baik, belum tentu produk tersebut akan dapat diterima di pasar oleh konsumen, maka hal ini belum tentu dapat meningkatkan volume penjualan. Selama ini memang banyak perusahaan yang beranggapan kalau kualitas produk ditingkatkan, maka volume penjualan pun juga akan meningkat. 
Berdasarkan uraian tersebut, peneliti tertarik untuk mengangkat penelitian dengan judul pengaruh jenis produk terhadap volume penjualan hand phone android di counter Clinik Android Madiun.

Dari rumusan masalah yang ada peneliti ingin mengetahui seberapa besar pengaruh jenis produk yang ada terhadap volume penjualan. Apakah dengan beragamnya jenis produk yang disediakan dapat meningkatkan volume penjualan yang ada atau tidak. Hal ini bertujuan untuk mengetahui seberapa besar pengaruh jenis produk terhadap volume penjualan.

Dengan penambahan jenis produk yang ada, diharapkan akan meningkatkan volume penjualan. Hal ini, dapat dilihat dari banyaknya jenis produk yang ada akan mempengaruhi tingkat volume penjualan. Sebuah hand phone yang memiliki fitur lengkap akan dipasarkan dengan harga yang lebih mahal, karena hand phone tersebut memiliki kualitas yang baik. Semakin tinggi harga hand phone Android, maka semakin lengkap fitur yang dimiliki. Sebab jenis hand phone Android yang harganya lebih mahal biasanya dianggap lebih berkualitas dibandingkan dengan jenis hand phone Android yang harganya lebih murah. Hal ini dipertegas Hani Handoko (2002: 54) "Kualitas merupakan faktor yang terdapat dalam suatu produk yang menyebabkan produk tersebut bernilai sesuai dengan maksud untuk apa produk itu dibuat".

"Pada umumnya tingkat harga yang lebih rendah akan mengakibatkan jumlah yang diminta lebih besar" (Basu Swastha, 2008:243). Dengan kata lain, pada tingkat harga yang lebih rendah pada umumnya akan mempengaruhi peningkatan volume penjualan, sebaliknya apabila harga tinggi maka volume penjualan akan menurun. Sebab, konsumen akan beralih jika harga suatu barang naik dan pada tingkat harga tinggi maka konsumen akan berpindah ke produk pengganti yang harganya lebih murah.

Dalam penelitian ini yang menjadi variabel bebas $(\mathrm{X})$ adalah jenis produk dan variabel terikat (Y) adalah volume penjualan. Adapun populasi dalam penelitian ini adalah bulan. Sedangkan sampel dalam penelitian ini sebanyak 24 bulan yang dimulai dari bulan Januari 2011 sampai Desember 2012.

Dalam menjaga kelangsungan kehidupan perusahaan terdapat kebijakan tertentu tentang tingkat produksi dan tingkat persediaan barang. Pada umumnya, konsumen memiliki banyak pilihan dalam membeli produk hand phone yang diinginkan, mulai dari pemilihan counter hand phone hingga jenis produk hand phone yang ingin dibeli. Dengan jumlah produk hand phone yang bervariasi maka akan mempermudah konsumen dalam menentukan pilihan mereka. Oleh karena itu tujuan penelitian ini adalah untuk mengetahui bagaimana Pengaruh Jenis Produk Terhadap Volume Penjualan Hand Phone Android Di Counter Clinik Android Madiun.

\section{METODE PENELITIAN}

Penelitian ini dilakukan di Counter Clinik Android di Jalan Serayu Madiun. Penelitian ini termasuk dalam kelompok penelitian kuantitatif dimana data yang digunakan berbentuk angka. Jenis penelitian berupa deskriptif korelatif yang artinya penelitian ini memiliki tujuan untuk melihat hubungan antara dua variabel atau lebih.

Dalam penelitian ini yang menjadi variabel bebas $(\mathrm{X})$ adalah jenis produk hand phone Android di Counter Clinik Android Madiun yang datanya diambil dari data dokumentasi berupa daftar harga hand phone android, karena baik atau tidaknya jenis produk salah satunya ditentukan oleh harga dari produk tersebut, sedangkan yang menjadi 
variabel terikat adalah volume penjualan hand phone android pada Counter Clinik Android Madiun yang datanya diambil dari data dokumentasi berupa data penjualan hand phone android di Counter Clinik Android Madiun.

Maka peneliti dapat menyimpulkan bahwa sampel merupakan bagian dari populasi. Sampel dalam penelitian ini yaitu 24 bulan, yang diambil dari data dokumentasi penjualan hand phone android di Counter Clinik Android Madiun selama 2 Tahun (24 Bulan).

Teknik pengumpulan data yang digunakan dalam penelitian ini adalah teknik dokumentasi, yaitu berupa data tutup bulanan/clossing di Counter Clinik Android Madiun pada bulan Januari 2011 sampai dengan bulan Desember 2012.

Maka dari itu, sampel harus diambil representative, yang berarti harus mewakili seluruh populasi sehingga pemilihan sampel harus dapat memberikan gambaran seluruh populasi.

Teknik pengambilan sampel yang digunakan oleh peneliti adalah teknik nonrandom sampling atau mengambil sampel yang ada. Sedangkan samplingnya disebut nonprobability sampling dengan menggunakan metode purposive sampling.

Sedangkan Teknik analisa data penelitian ini menggunakan regresi linear sederhana, teknik analisa ini digunakan untuk mengetahui pengaruh jenis produk terhadap volume penjualan hand phone di Counter ClinikAndroid Madiun.

\section{HASIL PENELITIAN}

\section{Variabel Jenis Produk}

Deskripsi variabel jenis produk (X) dalam penelitian ini yaitu terdiri dari bermacam-macam merek hand phone android yang terdiri dari Sony Ericsson, Samsung dan LG yang harganya sangat bervariasi. Perbedaan harga pada setiap tipe hand phone android ini disebabkan oleh kualitas dari masing-masing tipe hand phone android tersebut.

Kualitas dari masing-masing setiap tipe hand phone android ini sangat berperan dalam keberhasilan penjualannya di pasaran. Jika produk tersebut memiliki kualitas yang bagus maka dapat dengan mudah diterima oleh konsumen, begitu juga sebaliknya, namun jika produk tersebut memiliki kualitas rendah akan sulit diterima oleh konsumen. Hal ini disebabkan sifat konsumen yang selektif dalam pemilihan produk dan biasanya konsumen beranggapan bahwa jenis produk yang harganya mahal memiliki kualitas yang tinggi, begitu pula sebaliknya.

Dari data dokumentasi yang terdiri dari 17 tipe hand phone android dengan harga yang bervariasi dan dinyatakan dalam satuan Rupiah. Dari penelitian diperoleh data bahwa produk yang paling banyak diminati oleh konsumen adalah Samsung Galaxi Mini S5570 dengan harga Rp. 1.470,- berikutnya adalah Samsung Galaxi Ace 5830 dan lainlainnya yang harganya jauh lebih mahal dibandingkan dengan Samsung Galaxi Mini S5570. Sedangkan Samsung Galaxi S2 19100 yang harganya Rp. 5.129,- jarang diminati oleh konsumen.

\section{Variabel Volume Penjualan}

Deskripsi variabel volume penjualan (Y) dalam penelitian ini terdiri dari jumlah seluruh penjualan merek hand phone android yang terdiri dari Sony Ericsson, Samsung dan LG dalam setiap bulannya pada bulan Januari 2011 sampai bulan Desember 2012 yang dinyatakan dalam satuan unit barang yang terjual. Perbedaan volume penjualan pada setiap tipe hand phone android ini disebabkan 
oleh kualitas dari masing-masing tipe hand phone android tersebut.

Volume penjualan setiap tipe hand phone android di Counter Clinik Android Madiun ini diperoleh dari dokumentasi berupa data tutup bulanan di Counter Clinik Android Madiun selama 24 bulan (Januari 2011 sampai dengan Desember 2012).

Dari penelitian dapat dilihat dalam persentase bahwa volume penjualan hand phone android di Counter Clinik Android Madiun terbanyak adalah Samsung dengan persentase penjualan mencapai 46,59\%, disusul dengan LG dengan 32,63\% dan Sony Ericsson dengan 20,78\%.

\section{Hasil Uji Korelasi}

Dalam uji korelasi diperoleh nilai $r_{\text {hit }}$ sebesar -0,573681 sedangkan $r_{\text {tabel }}$ sebesar 0,514 . Hal ini berarti $r_{\text {hit }}<r_{\text {tabel }}(-0,573681<$ 0,514). Jadi dapat disimpulkan bahwa $\mathrm{H}_{0}$ diterima artinya tidak ada hubungan antara jenis produk terhadap volume penjualan hand phone android di Counter Clinik Android Madiun.

\section{Ujit}

Atas dasar tabel uji t di atas dapat dibuat persamaan regresi diperoleh persamaan nilai $Y=59,83131-0,005596808 x$ maka dapat diartikan jika jenis produk lebih unggul $1 \%$ maka volume penjualan akan mengalami penurunan sebesar -0,005596808\% sedangkan faktor lainnya tetap.

Dalam uji koefisien regresi/uji t diperoleh nilai $t_{\text {hit }}$ sebesar -2,69 sedangkan $t_{\text {tabel }}$ sebesar 1,753. Hal ini berarti $t_{\text {hit }} \leq t_{\text {tabel }}$ $(2,69 \leq 1,753)$. Maka dapat disimpulkan bahwa $\mathrm{H}_{0}$ diterima, artinya jenis produk tidak memiliki beda pengaruh terhadap volume penjualan hand phone android di Counter Clinik Android Madiun.

\section{Simpulan Hasil Analisis}

Atas dasar hasil pengujian hipotesis dapat diambil simpulan sebagai berikut.

\section{Simpulan Uji Korelasi}

Hasil dari pengujian korelasi diperoleh nilai $r_{\text {hit }}$ sebesar -0,573681 sedangkan $r_{\text {tabel }}$ sebesar 0,514. Hal ini berarti $r_{\text {hit }}<r_{\text {tabel }}$ $(0,573681<0,514)$. Jadi sesuai hipotesis yang diajukan dapat disimpulkan bahwa $\mathrm{H}_{0}$ diterima artinya tidak ada hubungan antara jenis produk terhadap volume penjualan hand phone android di Counter Clinik Android Madiun.

Maka sesuai hipotesis yang diajukan dapat diperoleh simpulan bahwa $\mathrm{H}_{0}$ diterima, artinya tidak ada hubungan antara jenis produk terhadap volume penjualan hand phone android di Counter Clinik Android Madiun.

\section{Simpulan Ujit}

Dari hasil pengujian yang dilakukan diperoleh persamaan regresi dengan nilai $Y=59,83131-0,005596808 x$ maka dapat diartikan jika jenis produk lebih unggul 1\% maka volume penjualan akan mengalami penurunan sebesar -0,005596808\% sedangkan faktor lainnya tetap.

Maka sesuai hipotesis yang diajukan dapat diperoleh simpulan bahwa $\mathrm{H}_{0}$ diterima, artinya jenis produk tidak memiliki beda pengaruh terhadap volume penjualan hand phone android di Counter Clinik Android Madiun.

Dalam uji koefisien regresi/uji t diperoleh nilai $t_{\text {hit }}$ sebesar $-2,69$ sedangkan $t_{\text {tabel }}$ sebesar 1,753. Hal ini berarti $t_{\text {hit }} \leq t_{\text {tabel }}(-2,69 \leq$ 1,753). Maka sesuai hipotesis yang diajukan dapat disimpulkan bahwa $\mathrm{H}_{0}$ diterima, artinya jenis produk tidak memiliki beda pengaruh terhadap volume penjualan hand phone android di Counter ClinikAndroid Madiun. 


\section{PEMBAHASAN}

\section{Pembahasan Uji Korelasi}

Dalam uji korelasi diperoleh nilai $\mathrm{r}_{\text {hit }}<$ $\mathrm{r}_{\text {tabel }}(-0,573681<0,514)$. Hal ini berarti $\mathrm{r}_{\text {hit }}<$ $\mathrm{r}_{\text {tabel }}(-0,573681<0,514)$. Jadi dapat disimpulkan bahwa $\mathrm{H}_{0}$ diterima artinya tidak ada hubungan antara jenis produk terhadap volume penjualan hand phone android di Counter Clinik Android Madiun.

\section{Pembahasan Uji t}

Dapat dilihat dari hasil persamaan regresi diperoleh persamaan $Y=59,83131$ $0,005596808 x$ sedangkan dalam uji koefisien regresi/uji $\mathrm{t}$ diperoleh nilai $\mathrm{t}_{\text {hit }} \leq \mathrm{t}_{\text {tabel }}(-2,69 \leq$ 1,753), maka dapat disimpulkan bahwa $\mathrm{H}_{0}$ diterima, artinya tidak ada beda pengaruh jenis produk terhadap volume penjualan hand phone android di Counter Clinik Android Madiun.

Dari hasil penelitian menunjukkan bahwa jenis produk tidak mempunyai pengaruh terhadap volume penjualan. Artinya jenis hand phone yang fiturnya sedikit dan harganya murah lebih diminati oleh konsumen sehingga mengakibatkan volume penjualan lebih tinggi dan sebaliknya jenis hand phone yang lebih mahal dengan fitur yang lebih lengkap ternyata kurang diminati oleh konsumen sehingga dapat mengakibatkan volume penjualan menurun. Hal ini juga dipengaruhi oleh faktor-faktor lain, seperti harga, merk dan selera konsumen.

\section{PENUTUP}

\section{Simpulan}

1. Jenis produk hand phone android di Counter Clinik Android Madiun dalam uji korelasi diperoleh nilai $\mathrm{r}_{\text {hit }}<\mathrm{r}_{\text {tabel }}(0,573681$ $<0,514)$. Hal ini menunjukkan $\mathrm{r}_{\text {hit }}<\mathrm{r}_{\text {tabel }}$ $(-0,573681<0,514)$. Jadi dapat disim- pulkan bahwa tidak ada hubungan antara jenis produk terhadap volume penjualan hand phone android di Counter Clinik Android Madiun.

2. Volume penjualan produk hand phone android di Counter Clinik Android Madiun dalam uji koefisien regresi / uji t diperoleh nilai $t_{\text {hit }}$ sebesar $-2,69$ sedangkan $t_{\text {tabel }}$ sebesar 1,753. Hal ini berarti $t_{\text {hit }} \leq t_{\text {tabel }}$ $(-2,69 \leq 1,753)$. Maka dapat disimpulkan jenis produk tidak memiliki beda pengaruh terhadap volume penjualan hand phone android di Counter Clinik Android Madiun.

3. Tidak ada pengaruh antara jenis produk terhadap volume penjualan hand phone android di Counter Clinik Android Madiun. Yang artinya jenis hand phone yang fiturnya sedikit dan harganya murah lebih diminati oleh konsumen sehingga mengakibatkan volume penjualan lebih tinggi dan sebaliknya jenis hand phone yang lebih mahal dengan fitur yang lengkap ternyata kurang diminati oleh konsumen sehingga dapat mengakibatkan volume penjualan menurun. Hal ini dibuktikan dengan fungsi $Y=59,83131$ $0,005596808 x$ maka dapat diartikan jika jenis produk lebih unggul $1 \%$ maka volume penjualan akan mengalami penurunan sebesar -0,005596808\% sedangkan faktor lainnya tetap. Hal ini dibuktikan dengan adanya tabel penjualan dimana Samsung Galaxy S2 i9100 dengan harga Rp 5.190,- terjual 41 unit, Samsung Galaxy S i9100 dengan harga Rp 3.810 terjual 48 unit, Samsung Galaxy Nexus S dengan harga Rp 3.800,- terjual 44 unit, sedangkan Samsung Galaxy Gio s5660 dengan harga Rp 1.950,- terjual 55 unit dan Samsung Galaxy Mini s5570 dengan harga Rp 1.470,- terjual 71 unit. Jadi konsumen beranggapan bahwa dalam membeli hand 
phone biasanya konsumen lebih memperhatikan harga, fungsi dan kegunaan dalam hal memilih merek hand phone. Jenis hand phone yang harganya lebih murah dan fiturnya sesuai dengan kebutuhan konsumen ini lebih banyak diminati sehingga dapat meningkatkan volume penjualan.

\section{Saran}

\section{Bagi Perusahaan}

Selain memperhatikan harga produk hand phone yang terjangkau dan fitur dalam menjual produknya, maka Counter hand phone Clinik Android Madiun juga diharapkan untuk lebih memperhatikan loyalitas konsumen dalam hal memilih merek produk yang banyak diminati oleh konsumen dengan cara menambah jumlah persediaan barang yang banyak diminati oleh konsumen agar produk yang dijual tersebut cepat laku di pasaran sehingga mampu meningkatkan volume penjualan hand phone di Counter Clinik Android Madiun sehingga dapat tumbuh dan berkembang serta mampu bersaing dengan counter hand phone lain.

\section{Bagi Karyawan}

Diharapkan karyawan pada Counter Clinik Android Madiun mampu memberikan pelayanan yang lebih baik kepada konsumen. Mengetahui apa yang menjadi selera dan kebutuhan konsumen, serta diharapkan mampu mengetahui dan memahami produk yang mereka jual agar dapat memberikan informasi akan kelebihan produk hand phone bagi konsumen terkait dengan produk yang akan mereka beli.

\section{DAFTAR PUSTAKA}

Basu Swastha. 2002. Azas-Azas Marketing. Yogyakarta: Liberty.
Basu Swastha. 2002. Pengantar Bisnis Modern. Yogyakarta: Liberty.

Basu Swastha. 2008. Manajemen Pemasaran Modern. Yogyakarta: Liberty.

Burhan Bungin. 2009. Metodologi Penelitian Kuantitatif. Jakarta: Kencana Perdana Media Group.

Freddy Rangkuti. 2009. Strategi Promosi yang Kreatif. Bogor: PT. Gramedia Pustaka Utama.

Gabriel Amin Silalahi. 2003. Metodologi Penelitian dan Studi Kasus. Sidoarjo: CV.Citra Media.

Gunawan Adisaputro. 2010. Manajemen Pemasaran. Yogyakarta: STIM YKPN.

Gunawan Adisaputro. 2008. Manajemen Pemasaran. Yogyakarta: BPFEYogyakarta.

Husein Umar. 2011. Metode Penelitian Untuk Skripsi dan Tesis Bisnis. Jakarta: PT. Raja Grafindo Persada.

http://belajarilmukomputerdaninternet. blogspot.com/2013/06/pengambilankeputusan-dalam-pemasaran.html (diunduh 27 November 2013, 08.25 wib).

http:/globalonlinebook1.blogspot.com/ $2013 / 06 /$ faktor-faktor-volumepenjualan.html (diunduh 27 November 2013, 08.25 wib).

http://jurnal-sdm.blogspot.com/2009/ $07 /$ produk-definisi-klasifikasidimensi_30.html (diunduh 27 November 2013, 08.27 wib).

Iqbal Hasan. 2004. Analisis Data Penelitian dengan Statistik. Jakarta: PT. Bumi Aksara. 
J. Supranto. 2008. Statistik Teori dan Aplikasi. Jakarta: Erlangga.

Kotler, Philip. "2008". Prinsip-prinsip Pemasaran, Edisi 12, Jilid 1. Erlangga.

Kotler, Philip. "2008". Marketing Management, Thirteenh Edition, Jilid 1. Terjemahan oleh Bob Sabran. 2009. Erlangga.

Kotler, Philip. "Tanpa Tahun". Marketing Management, Thirteenh Edition, Jilid 2. Terjemahan oleh Bob Sabran. 2008. Erlangga.

M. Mursid. 2010. Manajemen Pemasaran. Jakarta: Bumi Aksara.

Panji Anoraga. 2007. Pengelolaan Bisnis dalam Era Globalisasi. Jakarta: Rineka Cipta.

Rika Ampuh Hadiguna. 2009. Manajemen Pabrik. Jakarta: PT. Bumi Aksara.
Suharsimi Arikunto. 2002. Prosedur Penelitian. Jakarta: PT. Rineka Cipta.

Sumadi Suryabrata. 2006. Metodologi Penelitian. Jakarta: PT. Raja Grafindo Persada.

Sumadi Suryabrata. 2012. Metodologi Penelitian. Jakarta: PT. Raja Grafindo Persada.

Sri Mulyono. 2005. Statistik Untuk Ekonomi \& Bisnis. Jakarta: LPFE UI.

T. Hani Handoko. "Tanpa Tahun". Dasardasar Manajemen Produksi dan Operasi. Yogyakarta: BPFEYogyakarta.

Thamrin Abdullah. 2012. Manajemen Pemasaran. Jakarta: PT. Raja Grafindo Persada. 